\author{
WILHELM REES \\ University of Innsbruck, Austria \\ (D) https://orcid.org/0000-0001-5780-6820
}

\title{
Pastoral Care for Migrants Canonical and Religious Related Legal Requirements on Asylum and on the Change of Religion
}

\begin{abstract}
Refugees and migrants have always been of particular concern to the Roman Catholic Church and its pastoral care. Even if the large influx of refugees happening in 2015 and 2016 is no longer the case, flight and migration are still relevant topics in Austria. The contribution deals with the historical development of canonical regulations, the situation of refugees and migrants in Austria, the legal basis, the implementation of asylum procedures and numbers, the statements of the Austrian Bishop's Conference, the access to a Church or religious community and converting from one to another, the question of the Catholic Church's necessity of salvation, regulations concerning catechumenate and the question of church asylum. It provides figures, data and facts, presents the canonical and state legal situation and analyses it. It tries to make weak points obvious and would like to provide help for future considerations.
\end{abstract}

Keywords: refugees, migration, canon law, asylum, Republic of Austria

Even if the large influx of refugees happening in 2015 and 2016 is not the case any longer, flight and migration are still relevant topics in Austria. ${ }^{1}$ In December 2017, the Protestant Church of Austria criticised

${ }^{1}$ Cf. Statistik Austria: Migration \& Integration. Zahlen. Daten. Indikatoren 2019. Wien 2019. Available online: https://www.bmeia.gv.at/fileadmin/user_upload/Zentrale/Integration/Integrationsbericht_2019/Migration-Integration-2019.pdf (accessed 10.06.2020); for details see: W. ReEs: “»Migration ist eine Schlüsselfrage für die Zukunft der Menschheit" (Papst Franziskus 2019). Kirchen- und religionsrechtliche Vorgaben 
"increasingly absurd" practices in the context of interviews conducted during asylum procedures, ${ }^{2}$ which are still carried out today. As a member of the High Consistory Karl Schiefermaier mentioned, the questions asked as a part of credal tests "could not be answered by $90 \%$ of Austrian Protestants." Subsequently, applications for asylum are rejected due to lack of knowledge or the assumption that the applicant has undergone a fake conversion. ${ }^{3}$ Apart from that, Free Church generous practice of baptism and the idea of affecting one's own asylum procedure positively by receiving baptism made inquiries regarding ecclesiastical baptismal practice and lead to questions concerning sincerity of single person's wish for baptism. According to Islamic law, denouncing Islam (apostasy) is illegal; converted people have to expect persecution, jail and death penalty, as well as discrimination in terms of inheritance and matrimonial law once they return to their home country. This is why the deportation of Muslims who converted to Christianity - forz ecample, back to Iran - is more difficult. On the other hand: "What would Austria be without migrants?" Certainly "a much less populated country than it is today," a country with less individual and economic gain and a country with substantial staff sortages within the branches of tourism and care. ${ }^{4}$ In his message to International Day of Peace 2001 Pope John Paul II (1978-2005) also pointed towards this: "In the case of many civilizations, immigration has brought new growth and enrichment" or at least "have shown that they

zu Asyl, Religionswechsel und Seelsorge an Migranten in Österreich.” In: Festschrift für Johann Hirnsperger (KST). Eds. W. ReES, S. HAERING. Berlin 2020 (in press).

2 According to UNHCR Österreich: Flucht und Asyl in Österreich. Die häufigsten Fragen und Antworten. 5Wien (available online: http://www.unhcr.org/dach/wp-content/uploads/sites/27/2018/01/AT_UNHCR_Fragen-und-Antworten_2017.pdf — accessed 10.06.2020), asylum procedure is to decide "if an asylum seeker is granted asylum and if he can stay in Austria as a recognised refugee or if he receives a different form of protection (e.g. subsidiary protection). See also Republik Österreich. BundeSMINISTERIUM FÜR INNERES: Asyl. Begriffsbestimmungen. Available online: https://www.bmi.gv.at/301/ Allgemeines/Begriffsbestimmungen/start.aspx (accessed 10.06.2020); ÖSTERREICH.GV.AT: Asyl. Aktuelle Informationen zu Asyl, Asylverfahren, Familienverfahren, Ausweise und Dokumente, Rechtsberatung [1.01.2020]. Available online: https://www.oesterreich.gv.at/ themen/leben_in_oesterreich/asyl.html (accessed 10.06.2020); DiaKoniE: Kleines AsylLexikon. Available online: https://diakonie.at/kleines-asyl-lexikon (accessed 10.06.2020).

${ }^{3}$ Karl Schiefermaier quoted from Evang.AT: Pfarrgemeinden leisten wertvolle Integrationsarbeit. Oberkirchenrat Schiefermair kritisiert „absurde“ Glaubensprüfungen im Asylverfahren [20.12.2017]. Available online: https://evang.at/oberkirchenrat-pfarrgemeindenleisten-bei-fluechtlingen-wertvolle-integrationsarbeit [accessed 10.06.2020].

${ }^{4}$ I. BRICKNER: Wie wäre Österreich ohne Migranten? Wie wäre Österreich heute, hätte man die Grenzen vor Jahrzehnten dichtgemacht? Die Vision eines Landes ohne Zuzug von außen [1.09.2018]. Available online: https://derstandard.at/2000085768375/Wie-waereOesterreich-ohne-Migranten (accessed: 4.05.2019). 
are able to live together, respecting each other and accepting or tolerating the diversity of customs." ${ }^{5}$ However, also fear and anxiety arise, so that migration and flight become a safety issue. ${ }^{6}$

\section{The Roman Catholic Church and refugees and migrants}

Refugees and migrants have always been of particular concern to the Roman Catholic Church and its pastoral care. ${ }^{7}$ Caritas and other organizations as well as individual Christians are heavily involved in the ministration to migrants and refugees.

The Second Vatican Council (1962-1965) explicitly turned towards "migration" as a phenomenon (cf. Art. 63; 65; 84; 85;87 VatII GS), inculcated "reverence for man" (Art. 27 VatII GS) and demanded a "more humane and just condition of life" for all persons (Art. 29 VatII GS). The Community of nations and international organizations have been called "to alleviate the distressing conditions in which refugees dispersed throughout the world find themselves, or also to assist migrants and their families" (Art. 84 VatII GS). Therefore, particular responsibility is incurred by bishops, Bishops' Conferences (Art. 18 VatII CD), and laypersons (Art. 10 VatII AA). Thus, also Catechism of the Catholic Church binds the wealthy nations to "receive foreigners in need for safety and possibility of living which cannot be found in their home country" (Nr. $2242 \mathrm{KKK}$ ). The current legal canonical code (Codex Iuris Canonici 1983 (CIC/1983)) contains regulations regarding parish priests (c. $529 \$ 1 \mathrm{CIC} / 1983$ ) and

${ }^{5}$ John Paul II: Nuntius ob diem paci dicatum: Diálogo entre las culturas para una civilización del amor y la paz [8.12. 2000], Nr. 12. AAS 93 (2001), pp. 234-247. Available online: https://w2.vatican.va/content/john-paul-ii/de/messages/peace/documents/ hf_jp-ii_mes_20001208_xxxiv-world-day-for-peace.html (accessed 10.06.2020); further messages at https://w2.vatican.va/content/john-paul-ii/de/messages/peace.index.html (accessed 10.06.2020); cf. IDEm: Epistula Apostolica „Novo millennio ineunte“ Episcopis clero fidelibus Magni Iubilaei anni MM sub exitum [6.01. 2001], Nr. 55. AAS 93 (2001), pp. 266-309. Available online: https://w2.vatican.va/content/john-paul-ii/la/apost_letters/2001/documents/hf_jp-ii_apl_20010106_novo-millennio-ineunte.html (accessed 10.06.2020).

${ }^{6}$ Cf. G. Hauser: “Migration - ein Sicherheitsproblem?” In: Westliche, universelle oder christliche Werte? Menschenrechte, Migration, Friedenspolitik im Europa des 21. Jahrhunderts (= Ethica Themen. Institut für Religion und Frieden). Eds. G. MARCHL, C. WAGNSONNER. Wien 2012, pp. 75-99.

7 See W. ReEs: Migration (Fn 1). 
diocesan bishops (c. $383 \$ 1 \mathrm{CIC} / 1983$; cf. c. $192 \S 1$ CCEO). ${ }^{8}$ Furthermore, the local ordinary is obliged to nominate chaplains (cappellani) responsible for pastoral care regarding migrants and refuges (cf. c. 568 CIC/1983), which is reinforced by the Directory for the Pastoral Ministry of Bishops (22nd of February 2004). ${ }^{9}$ In addition, Pontifical Council for the Pastoral Care of Migrants and Itinerant People tailored pastoral care with migrants to this situation due to the instruction Erga migrantes caritas Christi (EM) in May 2004. ${ }^{10}$ During his first trip, which lead him to Lampedusa in 2013, Pope Francis emphasised that "advocacy of refugees and people in need will be one of the priorities of his papacy." ${ }^{11}$ His deep concern for the vulnerable and especially for refugees and migrants, above all is expressed in his Apostolic Letter "Evangelii Gaudium" (24th of November 2013). ${ }^{12}$ Moreover, in his Post-synodal Apostolic Exhortation "Christus vivit" (25th of March 2019) he admonishes young people, "not to play into the hands of those who would set them against other young people, newly arrived in their countries, and who would encourage them to view the latter as a threat, and not possessed of the same

8 Cf. S.J. Lederhilger: "Seelsorge am Menschen unterwegs." In: HdbKathKR3, pp. 768-775, esp. pp. 771-775; V. De PAolis: "L'impegno della Chiesa nella pastorale della mobilità umana secondo il Codice di Diritto Canonico." Seminarium 25 (1985), pp. 130c-155c.; G. KATZINGER: Kirchenrechtliche Anmerkungen zur Migrantenseelsorge in einer globalisierten Welt. In: Recht - Bürge der Freiheit. Festschrift für Johannes Mühlsteiger SJ zum 80. Geburtstag (= KST 51). Eds. K. Breitsching, W. ReEs. Berlin 2006, pp. 787-826, here pp. 807-813.

9 Cf. Congregatio pro Episcopis: Direttorio per il Ministero pastorale dei Vescovi „Apostolorum successors." Città del Vaticano 2004, Nr. 206a and b. Available online: http://www.vatican.va/roman_curia/congregations/cbishops/documents/rc_con_cbishops_doc_20040222_apostolorum-successores_en.html (accessed 10.06.2020).

10 Cf. Pontificium Consilium de Spirituali Migrantium atque Itinerantium Cura: Instruktion „Erga migrantes caritas Christi“ (3 May 2004). AAS 96 (2004), pp. 762-822. Available online: http://www.vatican.va/roman_curia/pontifical_councils/migrants/documents/rc_pc_migrants_doc_20040514_erga-migrantes-caritas-christi_ge.html (accessed 10.06.2020); G. Katzinger: Anmerkungen (Fn 8), pp. 813-825.

11 Cf. Vatican News: Vor fünf Jahren: Franziskus bei Migranten auf Lampedusa. Es war die erste Reise als Papst überhaupt: Vor genau fünf Jahren besuchte Franziskus Migranten auf der Insel Lampedusa vor Sizilien. Und warf einen Kranz ins Meer, zum Gedenken an alle während der Überfahrt nach Europa Verstorbenen [6.07.2018], https://www.vaticannews. $\mathrm{va/de/papst/news/2018-07/franziskus-papst-besuch-fluechtlinge-lampedusa-migranten.}$ html (accessed 10.06.2020).

12 Cf. Francis: Adhortatio Apostolica „Evangelii gaudium“ Episcopis, Presbyteris ac diaconis viris et mulieribus consecratis omnibusque christifidelibus laicis de evangelio nuntiando nostra aetate [24.11.2013]. AAS 105 (2013), pp. 1019-1137. Available online: http://w2.vatican.va/content/francesco/de/apost_exhortations/documents/papa-francesco_esortazione-ap_20131124_evangelii-gaudium.html (accessed 10.06.2020). 
inalienable dignity as every other human being." 13 Within the current reform of the Curia, ${ }^{14}$ Vatican established the Dicastery for Promoting Integral Human Development on 1st of July 2017. According to Motu Proprio "Humanam progressionem" (31st of December 2016), this dicastery "will be competent particularly in issues regarding migrants, those in need, the sick, the excluded and marginalised, the imprisoned and the unemployed, as well as victims of armed conflicts, natural disasters, and all forms of slavery and torture." 15 As Tobias Keßler mentions, the incorporation of different Vatican authorities (e.g. the Pontifical Council for the Pastoral Care of Migrants and Itinerate People) within this superagency is questionable as it "counteracts" growing significance of migration in the process of globalisation. Although, Pope Francis "does not tire of emphasizing the needs of refugees and migrants and of advocating for them," this superagency "causes certain insecurities regarding the Catholic Church's future commitment concerning the importance of flight and migration." 16

${ }^{13}$ FrancIs: Nachsynodales Apostolisches Schreiben „Christus vivit“ an die jungen Menschen und an das ganze Volk Gottes [25.03.2019], Nr. 94. Available online: http:// w2.vatican.va/content/francesco/de/apost_exhortations/documents/papa-francesco_esortazione-ap_20190325_christus-vivit.html (accessed 10.06.2020).

14 On the reform of the Curia, see W. ReEs: "Reformen in der römisch-katholischen Kirche. Kirchenrechtliche Neuerungen und Visionen von Papst Franziskus." ÖARR 64 (2017), pp. 410 -427 (= Herbert Kalb zum 60. Geburtstag).

15 Francis: Litterae Apostolicae Motu Proprio datae "Humanam Progressionem" quibus Dicasterium ad integram humanam progressionem fovendam constituitur [17.08.2016]. AAS 108 (2016), p. 968. Available online: https://w2.vatican.va/content/francesco/la/ motu_proprio/documents/papa-francesco-motu-proprio_20160817_humanam-progressionem.html (accessed 10.06.2020);

see also IDEm: Statuto del Dicasterio per il Servizio dello sviluppo umano integrale (17.08.2016). AAS 108 (2016), pp. 969-972. Available online:

http://w2.vatican.va/content/francesco/it/motu_proprio/documents/papa-francesco_20160817_statuto-dicastero-servizio-sviluppo-umano-integrale.html (accessed 10.06.2020). Art. 142-153 of Pastor bonus ceased to be in force. On current regulations see John Paul II: Constitutio Apostolica "Pastor Bonus" de Romana Curia [28.06.1988], Nr. 149-151. AAS 80 (1988), pp. 841-912, here pp. 899-900. Available online: http://w2.vatican.va/content/john-paul-ii/la/apost_constitutions/documents/hf_jp-ii_ apc_19880628_pastor-bonus-index.html (accessed 10.06.2020).

${ }^{16}$ T. Kessler: Kurienreform. Die Zusammenführung verschiedener Dikasterien betrifft auch die Migrantenseelsorge. Available online: https://iwm.sankt-georgen.de/kurienreform-betrifft-auch-migrantenseelsorge (accessed 10.06.2020). 


\section{On the situation of refugees and migrants in Austria}

"Austria has always been a country of immigration."17 Moreover, the asylum law of the Austrian Republic is based on international, European and national state law.

\subsection{Legal basis in Austria}

In Austria foreigners have three options to claim the right of permanent residence: EU-/EEA-citizens and their relatives receive the right of permanent residence after five years of legal residence ${ }^{18}$ and third-countrynationals receive it by residence permit, ${ }^{19}$ while persons qualified for asylum first receive a temporary residence permit valid for three years before they receive an unlimited right of permanent residence. ${ }^{20}$ As far as international law is concerned, Austria pledges itself to grant asylum and provide cover to those people who left their home country for reasons defined either in Geneva Refugee Convention (GRC, 28th of July 1951) or in New

${ }^{17}$ L. VenCSER: "Der pastorale Dienst für Migranten/Migrantinnen - Muttersprachliche Seelsorge." In: Migration und Integration: Pastorale Herausforderungen und Chancen. Eds. W. Krieger, B. Sieberer. Linz 2013, pp. 54-75; esp. pp. 59-61, here p. 59.

18 Cf. Directive 2004/38/EC of the European Parliament and of the Council of 29 April 2004 on the Right of Citizens of the Union and Their Family Members to Move and Reside Freely within the Territory of the Member States Amending Regulation (EEC) No 1612/68 and Repealing Directives 64/221/EEC, 68/360/EEC, 72/194/EEC, 73/148/EEC, 75/34/EEC, 75/35/EEC, 90/364/EEC, 90/365/EEC and 93/96/EEC (Text with EEA relevance). Available online: https://eur-lex.europa.eu/legal-content/DE/ALL/?uri=CELEX\%3A32004L0038 (accessed 10.06.2020); Bundesgesetz über die religiöse Kindererziehung 1985, §5. In: BGBI. Nr. 155/1985. Available online: https://www.ris.bka.gv.at/GeltendeFassung.wxe?Abfrage= Bundesnormen\&Gesetzesnummer=20004242 (accessed 10.06.2020).

${ }^{19}$ Cf. $\S \S 41-46$ NAG (Fn 18).

${ }^{20}$ Novelle „Asyl auf Zeit" (in force since June 2016); on this: KurIER: Regierung beschließt „Asyl auf Zeit“. ÖVP zufrieden: Österreich habe nun eines der schärfsten Asylgesetze in ganz Europa [26.01.2016]. Available online: https://kurier.at/politik/inland/ regierung-beschliesst-asyl-auf-zeit/177.262.265 (accessed: 10.02.2020). 
York Protocol relating to the status of refugees (31st of January 1967). ${ }^{21} 22$ Article 33 GRC prohibits expulsion and allocation on the part of the host country in cases where refugee's life or freedom are endangered. European Convention on Human Rights (ECHR, 4th of November 1950), ${ }^{23}$ which in Austria has constitutional rank by Federal Constitutional Law (BGBI 1964/59), does not mention flight or asylum directly, though it grants right to life (Art. 2 ECHR). Furthermore, it contains prohibition of torture (Art. 3 ECHR) and right to privacy and family life (Art. 8 ECHR). Article 18 of the Charter of Fundamental Rights of the European Union (hereafter: the Charter) appoints the right to asylum. ${ }^{24}$ The Treaty on the Functioning of the European Union demands common asylum policy in Europe. ${ }^{25}$ Moreover, the European Council implemented numerous regulations and directives realised by the Republic of Austria, for instance, the still disputed Dublin III Regulation ((VO/EU) 604/2013). This regulation contains criteria and procedures on the provision of the respective EU member state, which is responsible for asylum applications, whereby the competence of member states is defined. ${ }^{26}$

In accordance with Article 10(1) B-VG, in Austria the federal government is responsible for legislation and implementation concerning regu-

${ }^{21}$ Cf. UNHCR: Convention relating to the status of refugees and Protocol relating to the status of refugees. Available online: https://www.unhcr.org/3b66c2aa10.html (accessed 10.06.2020); concerning Austria: BGBl. Nr. 55/1955 und BGBl. Nr. 78/1974. Available online: https://www.ris.bka.gv.at/GeltendeFassung.wxe?Abfrage=Bundesnormen\&Gesetz esnummer=10005235 (accessed 10.06.2020) and https://www.ris.bka.gv.at/GeltendeFassung.wxe?Abfrage $=$ Bundesnormen \&Gesetzesnummer=10005394 $($ accessed 10.06.2020).

${ }^{22}$ As Ralf GeISLER: “Art. Asyl, Asylrecht (Th).” In: EvStLex9, Sp. 122-126, here Sp. 125 , mentions there were only a few countries with a "subjective legal claim to asylum (as in Germany, where the right of political asylum is a fundamental right)."

${ }^{23}$ Cf. European Convention for the Protection of Human Rights and Fundamental Freedoms (ECHR) [4.11.1950]. Available online: https://www.humanrights.ch/en/standards/ce-treaties/echr/ (accessed 10.06.2020); für Österreich BGBl. Nr. 210/1958. Available online: https://www.ris.bka.gv.at/GeltendeFassung.wxe?Abfrage=Bundesnormen\&Gesetz esnummer=10000308 (accessed 10.06.2020).

${ }^{24}$ Charter of Fundamental Rights of the European Union. Available online: https:// eur-lex.europa.eu/legal-content/EN/ALL/?uri=CELEX\%3A12012P\%2FTXT (accessed 10.06.2020).

25 Cf. Treaty on the Functioning of the European Union. Available online: https:// eur-lex.europa.eu/legal-content/EN/TXT/?uri=celex\%3A12012E\%2FTXT (accessed 10.06.2020).

${ }^{26}$ Cf. Regulation (EU)NO 604/2013 of the European parliament and of the Council of 26 June 2013 establishing the criteria and mechanisms for determining the Member State responsible for examining an application for international protection lodged in one of the Member States by a third-country national or a stateless person (recast). Available online: https://eur-lex.europa.eu/LexUriServ/LexUriServ.do?uri=OJ:L:2013:180:0031:0059:EN: PDF (accessed 10.06.2020). 
lating and monitoring the entrance and leaving of federal territory, in addition to being in charge of deportation and surrender. According to Article 15a B-VG, the federal government is also "responsible for supplying asylum seekers during the procedure. If the asylum procedure is approved, the federal provinces take over responsibility, which means that they have to take care for housing and supplying of the asylum seekers. Unaccompanied minors and Dublin-cases remain in federal minimum guarantee (Bundesbetreuung). Federal law on asylum (Asylgesetzt $2005-$ AsylG 2005) (BGBI. I Nr. 100/2005) ${ }^{27}$ specifies conditions and procedure of awarding and withdrawal of international protection. The Austrian Asylum Court has been responsible for issues of asylum from 1st of July 2008 until 31st of December 2013. ${ }^{28}$ In the course of the amendment of administrative jurisdiction 2012 this Court was merged with the Federal Administrative Court as of 1st of January 2014. As the Federal Ministry for the Interior emphasises, persons in need are granted "a fair asylum procedure, which complies to the rule of law and adheres the relevant European and International regulations." 29

\subsection{Implementation of asylum procedures and numbers}

Since 1st of January 2014 the Bundesamt für Fremdenwesen und Asyl (BFA) is responsible for the "implementation of first-instance asylum procedures along with residence permits for reasons to consider." While visa processes, rejections, monitoring etc. are still exercised by immigration

${ }^{27} \mathrm{Cf}$. Bundesgesetz, mit dem das Bundes-Verfassungsgesetz geändert wird, ein Asylgesetz 2005, ein Fremdenpolizeigesetz 2005 und ein Niederlassungs- und Aufenthaltsgesetz erlassen, das Bundesbetreuungsgesetz, das Personenstandsgesetz, das Bundesgesetz über den unabhängigen Bundesasylsenat, das Einführungsgesetz zu den Verwaltungsverfahrensgesetzen 1991, das Sicherheitspolizeigesetz, das Gebührengesetz 1957, das Familienlastenausgleichsgesetz 1967, das Kinderbetreuungsgeldgesetz und das Tilgungsgesetz 1972 geändert werden sowie das Fremdengesetz 1997 aufgehoben wird (Fremdenrechtspaket 2005). In: BGBl. I Nr. 100/2005. Available online: https://www.ris.bka.gv.at/eli/bgbl/I/2005/100 (accessed 10.06.2020).

${ }^{28}$ The legal basis was Article 129c to 129f B-VG and the Asylgerichtshofgesetz. Cf. Bundesgesetz über den Asylgerichtshof (Asylgerichtshofgesetz - AsylGHG). In: BGBl. I Nr. 4/2008. Available online: https://www.ris.bka.gv.at/GeltendeFassung.wxe ?Abfrage $=$ Bundesnormen $\&$ Gesetzesnummer $=20005660 \&$ FassungVom $=2013-12-31$ (accessed 10.06.2020).

29 Republik Österreich. Bundesministerium für Inneres: Asyl. Begriffsbestimmungen (Fn 2), Genfer Flüchtlingskonvention (GFK). 
policing, "coordination measures in the field of voluntary and compulsory return" also fall into the competence of BFA..$^{30}$

Due to legislative change in 2016 (Asyl auf Zeit), persons with refugee status in the sense of the definition according to GRC (entitled to asylum, convention-refugee or recognised refugee) are granted legal residence for at least three years before they receive a permit to stay in Austria. Provided that the applicant does not have a relevant reason for flight corresponding to GRC, he or she cannot be recognised as refugee. However, if there is a "relevant danger" of breaching Article 2 and 3 of the ECHR ${ }^{31}$ by sending a person back to their home country, he or she receives the status of subsidiary protection. If this is not the case, legitimacy of expulsion from Austria according to Article 8 of ECHR has to be considered. Nevertheless, expulsion is illegal, if there is another right of residence according to federal law (Niederlassungs- und Aufenthaltsgesetz-NAG) and according to European law or if expulsion would infringe upon Article 8 of the ECHR. Klaus Burger mentions expulsion and deportation ban enshrined within the "protection of human dignity." 32 Provided that Article 8 of the ECHR applies and if the asylum seeker is not recognised as refugee or as a person with subsidiary protection, he or she is to be deported to his or her home country. If the deported person does not fulfill this obligation, he or she will be brought out of the country ("zwangsweise Außerlandesbringung"). ${ }^{33}$ The asylum seeker is allowed to lodge a complaint against a negative decision at the Federal Administrative Court $(\mathrm{BVwG})$. In turn, he or she is allowed to lodge an appeal against the decision of the Federal Administrative Court at Higher Administrative Court $(\mathrm{VwGH})$ or to lodge a complaint to constitutional tribunal (VfgH).

Similar to Germany, the Republic of Austria has incurred a large influx of refugees and migrants during the recent years. ${ }^{34}$ In 2017, 1.97 million

30 Cf. Bundesamt für Fremdenwesen und Asyl: Asylverfahren. Wien o.J. Available online: https://www.bfa.gv.at/bmi_documents/1954.pdf (accessed 10.02.2020); see also RePUbliK ÖSTERreich. Bundesministerium FÜR InNEREs: Asyl. Begriffsbestimmungen (Fn 2).

31 Art. 2 ECHR bzw. 6. and 13. ZProtEMRK grant protection against death penalty or extralegal homicide. Article 3 of the ECHR protects against torture, inhumane or humiliating treatment or penalty. Available online: http://www.emrk.at/emrk.htm (accessed 10.06.2020).

32 K. Burger: Das Verfassungsprinzip der Menschenwürde in Österreich (= Europäische Hochschulschriften, Reihe II Rechtswissenschaft, Bd. 3429). Frankfurt a.M. u.a. 2002, p. 317; see also ibidem, p. 318.

33 Bundesamt für Fremdenwesen und Asyl: Asylverfahren (Fn 30), p. 22.

34 According to Republik Österreich. Bundesministerium für InNEREs: Asyl. Begriffsbestimmungen (Fn 2) migrants are "people who wander from one residence or country to another in order to live and work there or to enhance their live conditions. They differ 
people with migrant background (23\%) lived in Austria, which is 72,400 people more than in 2016 (2015: 1.81 million). ${ }^{35}$ According to Statistik Austria, 154,700 people immigrated (2016: 174,300; 2015: 214,400); 15,400 of those were returning Austrians and 86,600 were people from the EU/EFTA. As much as $34 \%$ of the immigrants came from third countries. Similarly to $2014(28,064)$ there were 24,735 asylum applications in 2017, which is significantly fewer than in $2015(88,340)$ and 2016 $(42,285)$. Almost $40 \%$ of the applications were lodged by women (2016: 22,307; 2015: 14,413) and more than 5\% came from unaccompanied under- 18 -years-olds $(1,352) .{ }^{36}$

The numbers of persons who were granted asylum in 2017 was 21,767 (2016: 22,307; 2015: 14,413) ${ }^{37}$ and most of them were Syrian citizens $(11,827)$. In addition, 7,081 (2016: 3.699) persons received a limited right of residence (with subsidiary protection). Followed by Germany, Austria has the largest number of positive decisions (237 per 100,000 inhabitants) in Europe. Apart from Eastern European states, France, Italy, and Spain are far below that. ${ }^{38}$ As a "dissuasive measure", Austria implemented a "maximum for asylum procedures", which accounted 35,000 in 2017 but has been considerably undercut with about 20,000 approved procedures. ${ }^{39}$

Most recently, the number of asylum applications has been similar to that in $2010(11,012)$ and $2011(14,416)$. In 2018, the number of migrants $(146,900)$ and asylum applications $(13,476)$ was significantly below the previous year's level. Furthermore, Austria granted asylum to 14,696 persons, which is a decrease from $2017(21,767)$ by an amount of almost a third. Most of these negative decisions were given to Afghan citizens.

from refugees in not being haunted or prosecuted, but leaving their home country voluntarily and having the opportunity to go back without being suppressed."

35 Cf. in detail: StAtistik Austria: Migration \& Integration. Zahlen. Daten. Indikatoren 2018. Wien 2018, p. 9. Available online: https://www.bmeia.gv.at/fileadmin/user upload/Zentrale/Integration/Integrationsbericht_2018/Statistisches_Jahrbuch_2018.pdf (accessed 10.06.2020).

${ }^{36}$ Cf. ibidem, pp. 8, 36. An application for asylum has to be filed directly and in person in an Austrian admission district or at a police station.

37 According to Republik ÖsterReICH. Bundesministerium FÜr InNEREs: Asyl. Begriffsbestimmungen (Fn 2), asylum seekers are "people who search for asylum outside of their home country. Their asylum process is not completed yet. If they receive a positive message, their status changes from asylum seeker towards recognized refugee."

38 Cf. Statistik Austria: Migration \& Integration. Zahlen. Daten. Indikatoren 2018 (Fn 35), p. 38.

${ }^{39}$ Cf. ORF: Hunderte Muslime wechseln zum Christentum. Die Flüchtlingskrise beschert der katholischen Kirche in Österreich eine Rekordzahl an Menschen, die vom Islam zum Christentum wechseln. Allein in Wien haben sich 260 Menschen aus 15 Nationen taufen lassen [13.01.2018]. Available online: https://religion.orf.at/stories/2889262/ (accessed 10.06.2020). 
4,191 persons (2017: 7,081) especially from Afghanistan (2,062), Somalia (665), Iraq (536), and Syria (414) received a limited right of residence (with subsidiary protection). ${ }^{40}$ In 2019 the number of asylum applications totaled $12,886 .^{41}$

\section{The Austrian Catholic Church and migration}

As stated by Làzló Vencer, the Austrian Catholic Church strived to "offer special pastoral care to migrants and refugees" after the Second World War and in the years thereafter. ${ }^{42}$

\subsection{Statements of the Austrian Bishops' Conference}

Currently, the foreign-language pastoral care of the Austrian Roman Catholic Church conforms with the relevant pastoral and legal directives of the Austrian Bishops' Conference (6th of November 1997) ${ }^{43}$ and with the directives for ministration of National Director for foreign-language communities in the area of Austrian Bishops' Conference (6th of November 1997). ${ }^{44}$ Within the Austrian Bishops' Conference, Bishop Ägidius J.

40 See in detail Statistik Austria: Migration \& Integration. Zahlen. Daten. Indikatoren 2019 (fn 1), pp. 36-41.

${ }^{41}$ See at https://www.migration-infografik.at/asyl/at_asylstatistiken_2019/ (accessed 10.06.2020); for numbers for 2020, see https://www.migration-infografik.at/asyl/ at_asylstatistiken_2020 (accessed 10.06.2020). https://de.statista.com/statistik/daten/ studie/293189/umfrage/asylantraege-in-oesterreich (accessed 10.06.2020).

${ }^{42}$ L. VenCSER: Der pastorale Dienst für Migranten/Migrantinnen - Muttersprachliche Seelsorge (Fn 17), p. 61.

43 ÖsterReichische BischofsKonferenz: "Pastorale und rechtliche Richtlinien für die fremdsprachige Seelsorge in Österreich.” In: Amtsblatt der Österreichischen Bischofskonferenz, Nr. 22 vom 20. Mai 1998, Nr. II.1, pp. 4-8. Available online: https://www. uibk.ac.at/praktheol/kirchenrecht/teilkirchenrecht/oebiko/fremdsprachig.html (accessed 10.06.2020); https://www.bischofskonferenz.at/dl/klrsJKJKKoKKlJqx4nJK/Amtsblatt_der_Bischofskonferenz_Nr._22-20.05.1998.pdf (accessed 10.06.2020); https:// www.bischofskonferenz.at/pages/glossary_list.siteswift?s=3804\&t=bbd0a0a9e0bef15c \&ts $=1591176337$ (accessed 10.06.2020).

${ }^{44}$ Regarding Austria, see: Österreichische Bischofskonferenz: "Pastorale und rechtliche Richtlinien für die fremdsprachige Seelsorge in Österreich." In: Amtsblatt der Österreichischen Bischofskonferenz, Nr. 22 vom 20. Mai 1998, Nr. II.1, pp. 8-9. Available 
Zifkovics is responsible for the resort "Flight, Migration and Integration" and therefore he is accountable for pastoral care for migrants and foreignlanguage pastoral care.

Austrian Bishops' Conference (herafter: $\mathrm{ABC}$ ) commented on questions of flight and migration in various statements. ${ }^{45}$ On the 21st of April 2016, the ABC vehemently rejected the increase of asylum, which has been suggested by the federal government, ${ }^{46}$ and on the 5 th of October 2016 they spoke out against an asylum emergency decree. ${ }^{47}$ As ABC's General Secretary Peter Schipka emphasised on the 12th of April 2019, asylum seekers "should be able to be engaged in a paid and useful activity voluntarily during the ongoing procedure while the determination of maximum financial compensation for such activities of public utility should be avoided." 48 Within a statement on the law change of asylum system scheduled for the 12th of April 2019, the ABC resolutely demanded "legally valuable and independent asylum legal counsel, which 'explicitly sides with the asylum seeker.." ${ }^{49}$ Cardinal Christoph Schönborn even

online: https://www.uibk.ac.at/praktheol/kirchenrecht/teilkirchenrecht/oebiko/nationaldirektor.html (accessed 10.06.2020); https://www.bischofskonferenz.at/dl/klrsJKJKKoKKlJqx4nJK/Amtsblatt_der_Bischofskonferenz_Nr._22-20.05.1998.pdf (accessed 10.06.2020); ÖsterReichische BischofsKonferenz: "Fremdsprachige Seelsorge.” In:

Amtsblatt der Österreichischen Bischofskonferenz, Nr. 61 vom 5. Februar 2014. Nr. II.3, p. 11. Available online: https://www.uibk.ac.at/praktheol/kirchenrecht/teilkirchenrecht/ oebiko/seelsorge_fremdsp.html (accessed 10.06.2020); see also L. VencSER: Der pastorale Dienst für Migranten/Migrantinnen - Muttersprachliche Seelsorge (Fn 17), pp. 61-67.

45 Cf. Österreichische Bischofskonferenz: Asyl und Migration. Available online: https://www.bischofskonferenz.at/positionen/asyl (accessed 10.06.2020).

46 See Österreichische BischofsKonferenz: Bischofskonferenz lehnt geplante Asylverschärfung ab. Bischöfe kritisieren Gesetzesentwurf als negativen Paradigmenwechsel und nicht akzeptablen Eingriff in Grundrecht, der bestehendes Recht auf Asyl maßgeblich einschränkt - Warnung vor europaweiter Dynamik, die das Recht auf Asyl faktisch aushebelt [22.04.2016]. Available online: https://www.bischofskonferenz.at/asyl/bischofskonferenz-lehnt-geplante-asylverschaerfungen-ab (accessed 10.06.2020).

47 See Österreichische BischofsKonferenZ: Bischofskonferenz gegen Asylnotverordnung. Bischöfe orten keinen öffentlichen Notstand - Gegen Verschärfung des Asylrechts. Available online: https://www.bischofskonferenz.at/asyl/bischofskonferenz-gegen-asylnotverordnung (accessed 10.06.2020); statement at https://www.bischofskonferenz.at/ dl/rllNJKJKKMMmMJqx4KJK/2016_10_05_Bischofskonferenz_Stellungnahme_Asyl_ Notverordnung_BMI.pdf (accessed 10.06.2020).

48 Peter Schipka, quoted from Österreichische BischofsKonferenz: Bischofskonferenz gegen Asylnotverordnung. Bischöfe orten keinen öffentlichen Notstand - Gegen Verschärfung des Asylrechts. Available online: https://www.bischofskonferenz.at/asyl/ bischofskonferenz-gegen-asyl-notverordnung (accessed 10.06.2020).

49 See Österreichische BischofsKonferenz: Bischofskonferenz fordert eine parteiische Rechtsberatung [12.04.2019]. Available online: https://www.bischofskonferenz. at/125366/bischofskonferenz-fordert-parteiische-rechtsberatung (accessed 10.06.2020); text available for a download: https://www.bischofskonferenz.at/dl/lpLuJKJKkMLm- 
described the asylum policy of the former Austrian federal government as "inhumane." 50

In this context, questions concerning the request for baptism of refugees and migrants arose for the Austrian Bishops' Conference. As the figures of ABC's coordination office for catechesis and asylum show that 750 adults have been baptized in 2017, of whom " $75 \%$ had a Muslim background." 51 For 2019 ,the Catholic Church expected 500 baptisms of persons of 14 or above. ${ }^{52}$ Within the Protestant Church A.B. 209 asylum seekers were baptized in $2017 . .^{53}$

\subsection{Access to a Church or religious community and converting from one religion to another}

The freedom of joining a Church or religious community and converting from one religion or ideology to another is guaranteed by fundamental rights and self-evident to a free and democratic constitutional state. This fundamental right is based on religious and ideological neu-

mJqx4KJK/2019_04_12_BMI_BBU-Errichtungsgesetz_Stellungnahme_PDF.pdf (accessed 10.06.2020).

${ }^{50}$ Cf. Die Presse: „Unmenschlich“: Schönborn rechnet mit Asylpolitik der Regierung ab. In der ORF-,,Pressestunde“ übt Kardinal Christoph Schönborn scharfe Kritik an der Regierung: „Eine kleine Gruppe von Menschen wird offensichtlich systematisch in ein schiefes Licht gerückt" [14.04.2019]. Available online: https://diepresse.com/home/ panorama/religion/5612554/Unmenschlich_Schoenborn-rechnet-mit-Asylpolitik-derRegierung-ab (accessed 10.06.2020); on the programme of the new government see Die Neue Volkspartei/die Grünen - Die Grüne Alternative: Aus Verantwortung für Österreich. Regierungsprogramm 2020-2024, Nr. 04. Available online: https://www. dieneuevolkspartei.at/Download/Regierungsprogramm_2020.pdf (accessed 10.06.2020).

${ }^{51}$ ERZDIÖZESE WiEN: Österreichweit gab es 2017 bis zu 750 Erwachsenentaufen. Hauptgrund für die Zunahme von Taufbewerbern — sogenannten „Katechumenen“ — aus muslimischen Ländern, die im Zuge der Flüchtlingsbewegung nach Österreich kamen und Christen werden wollen [15.01.2018]. Available online: https:/www.erzdioezese-wien.at/ site/home/nachrichten/article/62769.html (accessed 10.06.2020). In 2014 the ABC's statistics counted 305 baptisms of adults, in 2015 there were 322 and 2016 there were 433 baptisms of adults. On details and current numbers see: https://www.katholisch.at/statistik (accessed 10.06.2020).

52 Cf. Katholische Kirche Österreich: Weiterhin hohe Zahl an katholischen Erwachsenentaufen. Kirche rechnet für 2019 mit 500 Taufen von Personen ab 14 Jahren, davon über 200 aus der Erzdiözese Wien [8.03.2019]. Available online: https://www.katholisch. at/aktuelles/124945/weiterhin-hohe-zahl-an-katholischen-erwachsenentaufen (accessed 10.06.2020).

53 Evang.at: Pfarrgemeinden leisten wertvolle Integrationsarbeit (fn 3). 
trality and the right of religious freedom. The Austrian Republic grants "full freedom of religious and conscience" (art. 14 abs. 1 StGG) ${ }^{54}$ while it leaves the regulation of membership to a particular Church or religious community in sense of an internal affair (cf. art. 15 StGG).$^{55}$ Paragraph 3 of the legal act of the 20th of May 1874 concerning legal recognition of religious communities (RGBI 1874/68; AnerkennungsG) explicitly assigns "the questions of belonging and accessing to a recognised religious community to their particular constitutions." ${ }^{56}$ According to $\$ 4$ abs. 11.4 of the federal law on legal personality of religious denominations (in German: BekGG) $)^{57}$ the membership in recognised Churches and religious communities and the membership in officially registered religious denominations ${ }^{58}$ are to be settled internally. As Herbert Kalb, Richard Potz and Brigitte Schinkele mention, hence, "the decision regarding the question if a person joining a religious community complies with the conditions is deprived of governmentally judgement." ${ }^{59}$ Regulations of a particular Church or religious community, in turn, are binding for the secular sector. The religious conversion of adolescents is regulated by federal law on religious parenting. ${ }^{60}$ Article 9 abs. 1 ECHR $^{61}$ (which pertains to Austrian

${ }^{54}$ Staatsgrundgesetz vom 21. December 1867 über die allgemeinen Rechte der Staatsbürger für die im Reichrathe vertretenen Königreiche und Länder, Art. 14 Abs. 1. In: RGBl. Nr. 142/1867. Available online: https://www.ris.bka.gv.at/GeltendeFassung.wxe?Ab frage $=$ Bundesnormen $\&$ Gesetzesnummer $=10000006$ (accessed 10.06.2020).

55 Staatsgrundgesetz vom 21. December 1867 (Fn 54), Article 15.

56 Gesetz vom 20. Mai 1874, betreffend die gesetzliche Anerkennung von Religionsgesellschaften (AnerkennungsG). In: RGBl. Nr. 68/1874. Available online: https://www.ris. bka.gv.at/GeltendeFassung.wxe?Abfrage $=$ Bundesnormen $\&$ Gesetzesnummer $=10009173$ (accessed 10.06.2020). Liste der Gesetzlich anerkannten Kirchen und Religionsgesellschaften in der Republik Österreich to be found at: https://www.bundeskanzleramt.gv.at/ kirchen-und-religionsgemeinschaften (accessed 10.06.2020).

57 On the particular state-registered religious communities in Austria see https:// www.bundeskanzleramt.gv.at/religiose-bekenntnisgemeinschaften (accessed 10.06.2020). Available online:

https://www.oesterreich.gv.at/themen/leben_in_oesterreich/kirchenein___austritt_ und_religionen/3/Seite.820016.html (accessed 10.06.2020); J. BAIR,W. ReEs: Staatlich eingetragene religiöse Bekenntnisgemeinschaften in Österreich (= Religion und Staat im Brennpunkt 3). Innsbruck 2018.

58 Cf. Bundesgesetz über die Rechtspersönlichkeit von religiösen Bekenntnisgemeinschaften. In: BGBl. I Nr. 19/1998. Available online: https://www.ris.bka.gv.at/GeltendeFassung.wxe?Abfrage $=$ Bundesnormen\&Gesetzesnummer $=10010098$ (accessed 10.06.2020).

59 Cf. H. Kalb, R. Potz, B. Schinkele: Religionsrecht. Wien 2003.

${ }^{60}$ Cf. Bundesgesetz über die religiöse Kindererziehung 1985, §5. In: BGBI. Nr. 155/1985.

${ }^{61}$ Cf. European Convention for the Protection of Human Rights and Fundamental Freedoms (ECHR) (FN 23), Art. 9 Abs. 1. 
federal constitution ${ }^{62}$ ?) and Article 18 UDHR both guarantee "the freedom of individuals to change religions or ideology" explicitly. ${ }^{63}$

\subsection{Concerning the question of the Catholic Church's necessity of salvation}

According to Second Vatican Council all people "are bound to seek the truth, especially in what concerns God and His Church, and to embrace the truth they come to know, and to hold fast to it" (art. 1 abs. 2 VatII $\mathrm{DH})$. The council concludes, that "whosoever, therefore, knowing that the Catholic Church was made necessary by Christ, would refuse to enter or to remain in it, could not be saved" (art. 14 abs. 1 VatII LG; cf. art. 7 abs. 1 VatII AG). Thus, belonging to the Catholic Church and therefore also the baptism seems to be necessary when it comes to salvation. Baptism incorporates into the Church of Jesus Christ and accordingly into the community of all baptized people, but it also incorporates into a particular church or church community. In case of adult baptism, a catechumenate is required (cf. c. 851, $1^{\circ} \mathrm{CIC} / 1983$; cf. art. 64 VatII SC and art. 14 VatII AG), which has to be specified by the actual bishop's conference (cf. c. 788 §3 CIC/1983; c. 587 \$ 3 CCEO). In case of infant baptism, parents and godfather/godmother "are to be instructed properly on the meaning of this sacrament and the obligations attached to it" (c. 851, $2^{\circ} \mathrm{CIC} / 1983$; cf. c. $686 \S 2$ CCEO), e.g. by conversation. ${ }^{64}$

\subsection{Regulations concerning catechumenate}

In Austria the catechumenate of adults conforms to ABC's order from the 6th of November 1992, ${ }^{65}$ which is binding to candidates aged 14 or

${ }^{62}$ According to V-VG (BGBI. Nr. 59/1964) the European Human Rights Convention is constitutional in Austria. See: https://www.ris.bka.gv.at/GeltendeFassung.wxe?Abfrage $=$ Bundesnormen\&Gesetzesnummer $=10000308$ (accessed 10.06.2020).

${ }^{63}$ Cf. Universal Declaration of Human Rights. Resolution 217 A (III) [10.12.1948]. Available online: http://hrlibrary.umn.edu/instree/b1udhr.htm (accessed 10.06.2020).

${ }^{64}$ Cf. Österreichische Bischofskonferenz, Richtlinien für die Einführung eines Taufgesprächs mit den Eltern vor der Spendung der Taufe vom März 1971, u.a. in: Verordnungsblatt für die Diözese Innsbruck, 46. Jg., Nr. 6 vom 1. Juni 1971, Nr. 47, p. 34.

${ }^{65}$ Cf. Österreichische BischofsKonferenz: "Dekret über die Ordnung des Katechumenats can. $788 \S 3$ und can. 851, beschlossen am 6. November 1992. Recognitio durch 
older $(§ 1)$. Due to the increasing number of asylum seekers searching for baptism, the Austrian bishops decided to specify the regulations on catechumenate of asylum seekers in 2015 as they felt a need for "special attention and mentoring regarding this area." ${ }^{66}$ When it comes to the catechumenate of asylum seekers, preparation takes "one year according to possibility"; if it is necessary, the preparation time "may take longer." The Austrian bishop's point out that - in line Austrian legal situation - "the desire for conversion to Christianity or a conversion already performed has to be taken into account for the asylum procedure if the change of religion caused the flight or if the conversion leads to the risk of being prosecuted in one's home country. Above all, this applies to the conversion of refugees coming from countries where Islam is the dominant religion." In the process the authorities have to ensure "that the conversion is not a mock one and results only from the scarcity of other reasons for asylum." Thus, the Church has to "verify the authenticity of the desire for baptism and she also has to pay attention to accurate implementation and sufficient duration of catechumenate." The Austrian bishop's point out that "an ongoing asylum procedure may also affect other family members." "If there is a desire for conversion of the whole family, the question remains if this corresponds to the will of all members. Adolescents who reached the age of 14 have to decide on their own and even young children must not be baptized or involved in catechumenate against their declared will."

The Austrian bishops emphasise that "discreetness within the whole process of baptism is vital to some asylum seekers." Furthermore, "the contact with Christians from concrete communities should be supported, so that the integration into the churchly community can take place." This may also be a way "to find appropriate sponsors." It is required that the concrete parishes have to be made ready for the inclusion of such persons." Even after the further support of baptism is required.

die Kongregation für die Bischöfe am 14. Januar 1994.” In: Amtsblatt der Österreichischen Bischofskonferenz, Nr. 11 vom 28. April 1994, Nr. II.2, pp. 3-4. Available online: https://www.uibk.ac.at/praktheol/kirchenrecht/teilkirchenrecht/oebiko/katechumenat. html (accessed 10.06.2020); see GENERALSEKRETARIAT DER ÖSTERREICHISCHEN BISCHOFSKOnferenz (Ed.): Katechumenat. Pastorale Orientierung (= Die österreichischen Bischöfe 14). Wien 2016. Available online: http://www.bischofskonferenz.at/dl/NpLLJKJKKoolOJqx4KlJK/Heft14_Katechumenat.pdf (accessed 10.06.2020).

66 ÖsterReICHISCHE BISCHOFSKONFERENZ: "Richtlinien der österreichischen Bischöfe zum Katechumenat von Asylbewerbern.” In: Amtsblatt der Österreichischen Bischofskonferenz, Nr. 65 vom 20. April 2015, Nr. II.1, pp. 9-14. Available online: https://www. uibk.ac.at/praktheol/kirchenrecht/teilkirchenrecht/oebiko/katechumenat-asylwerber. html (accessed 10.06.2020). 
When it comes to Muslims, the Austrian bishops request special clarity concerning particular content of faith, whereby "the belief in God as the One and Triune One, in Jesus Christ as true human being and true God, the role of the Mother of God within the salvation event, death and resurrection of Jesus, the forgiveness of sin, the Christian concept of humanity and the thereto related position of man and woman" are mentioned expressly. These firm regulations may be seen as discriminating; but at least they are necessary, as admitting persons to baptism, who are assessed as unreliable within the authority's procedure may lead to incredibility of the Church or the catechumenate in Austria."

With a view to adult catechumens the matrimonial situation has to be taken into account, which means that the canonical validity as well as opportunities to remediate the current marriage should be checked. From a pastoral point of view, it may be reasonable to permanent asylum seekers at a later time in order to spend the meantime for further catechumenate.

Just as the ABC did, also the Theologische Ausschuss der Generalsynode der Evangelischen Kirche A. und H.B. in Österreich published a guidance for baptism requests, baptism preparation lessons and baptism of asylum seekers in October $2014 .^{67}$

\section{On the question of Church asylum}

In connection with flight, migration, and state legislation in Austria, ${ }^{68}$ church asylum has to be considered more detailed. Just recently there are various cases of parishes accommodating refugees in order to counteract deportation and to cause a reopening of the asylum proceeding or an examination of government action. ${ }^{69}$

67 Theologischer Ausschuss der Generalsynode der Evangelischen Kirche A. Und H.B. IN Österreich: Handreichung für Taufanfragen, Taufunterricht und Taufe von Asylsuchenden vom Oktober 2014. Available online: http://www.okr-evang.at/handreichung Taufe_Asylsuchende/dokumente/Richtlinien_Generalsynode.pdf (accessed 10.06.2020).

${ }^{68}$ Cf. Die Presse: Kurz zu UNO-Migrationsbericht: „Lasse es nicht zu, Österreich schlechtzureden“. Das hiesige Asylverfahren weise Mängel auf, kritisiert das UN-Menschenrechtshochkommissariat. Kanzler Kurz weist die Vorwürfe zurück und fordert im Gegenzug eine Prüfung aller übrigen EU-Staaten [9.05.2019]. Available online: https://www.diepresse.com/5625131/kurz-zu-uno-migrationsbericht-lasse-es-nicht-zu-osterreich-schlechtzureden (accessed 10.06.2020).

${ }^{69}$ Cf. Die Presse: Salzburger Lehrling nach Kirchenasyl in Schubhaft. Nach zwei negativen Asylbescheiden wurde der 23-jährige Ali Wajid in Schubhaft genommen. Der Men- 
Christianity assumed the "institution of religious asylum from ancient religions" and - after its establishment as state religion in $380 \mathrm{AC}$ - "enshrined it for over 1,500 years within European legal culture." ${ }^{70}$ From the beginning of modernity church asylum was increasingly seen as hindrance to state judicature, so that it has been repressed due to the separation of state and church and, until now, it is no longer accepted. ${ }^{71}$

The CIC of 1917 (CIC/1917) granted an asylum right to the Church as well as it sanctioned breaches (cf. cc. 1179; 1160; 2325 CIC/1917). This right was not explicitly included into canonical law of 1983 (CIC/1983). Some canonical legal experts state that the Church waived an own asylum right, while others tried to proof the continued existence of this right. As Stephen Hearing mentions, the Roman Catholic Church "did not claim the holding of a ecclesiastical exception from state monopoly any longer." 72 Nevertheless, the Church may "expect that the public authority pays appropriate regard to the sanctity and to the special character of ecclesiastical places, so that they act in a respectful and gentle way, if they operate within this area." 73 Actions happening at a holy place, that "hurt or upset the faithful in a serious way" may lead to the desecration of this place (cf. c. $1211 \mathrm{CIC} / 1983$ ). The right to "always and everywhere [...] announce moral principles, even about the social order, and to render judgment concerning any human affairs insofar as the fundamental rights of the human person or the salvation of souls requires it" (c. $747 \$ 2$ CIC/1983; cf. c. 595 \$2 CCEO) remains with the Church.

schenrechtsaktivist ist nach wie vor um eine freiwillige Ausreise bemüht [24.01.2019]. Available online: https://diepresse.com/home/panorama/oesterreich/5568110/SalzburgerLehrling-nach-Kirchenasyl-in-Schubhaft (accessed 10.06.2020); Katholische KirChE ÖsterReICH: Erzdiözese Salzburg stützt „Gewissensentscheidung“ des Unkener Pfarrers, einen von Abschiebung bedrohten afghanischen Kochlehrling zu beherbergen [12.11.2019]. Available online: https://www.katholisch.at/aktuelles/127874/kirchenasyl-in-unkenkirche-fuer-vernunft-und-barmherzigkeit (accessed 10.06.2020).

${ }^{70}$ M. Pulte: Grundfragen des Staatskirchen- und Religionsrechts (= Mainzer Beiträge zu Kirchen- und Religionsrecht 1). Würzburg 2016.

${ }^{71}$ Regarding the abrogation in Austria see especially M. Bаво: Kirchenasyl - Kirchenhikesie. Zur Relevanz eines historischen Modells im Hinblick auf das Asylrecht der Bundesrepublik Deutschland (= Studien der Moraltheologie 20). Münster-Hamburg-London 2003, pp. 125-129.

${ }^{72}$ S. HaEring: "Kirche und Staat in der Sicht des Zweiten Vatikanischen Konzils und die Auswirkungen im Codex Iuris Canonici. Zur modernen Antwort der katholischen Kirche auf eine jederzeit aktuelle Frage." In: Ius canonicum in communione christifidelium. Festschrift 65. Geburtstag von Heribert Hallermann (= KStKR 23). Eds. M. GRAULich, T. Meckel, M. Pulte. Paderborn 2016, pp. 83-98, here p. 91.

${ }^{73}$ S. HAERING: Kirche und Staat in der Sicht des Zweiten Vatikanischen Konzils (Fn 72), pp. 91-92. 
Church asylum "assumes that federal order submits itself to the bids of religion or at least that federal order grant religion a legal vacuum."74 As Ralf Geißler emphasises, modern sovereign states are not able to tolerate varying law nor legal vacuum." ${ }^{75}$ Christian Traulsen rightly states that "a parish's accommodation of refugees does not change their legal position as well as it does not prevent the state to give effects to its rights." 76 The granting of church asylum is not covered by law in Austria. ${ }^{77}$ Church asylum contradicts the existing separation of state and church. Even though "the primary motivation for acting may be reasoned by Christian's duty to support rather than it is motivated by disagreeing to federal law," Brigitte Schinkele mentions "that church asylum comes close to the legal figure of "civil disobedience'." "78 Thus every person has to act according to his or her conscience while taking the risk of legal consequences.

\section{Perspectives}

As Statistik Austria stated in 2018, " $41 \%$ of questioned Austrian assess integration of migrants as 'rather bad' and further $13 \%$ assess integration of migrants 'as very bad'. In contrast, there are merely $4 \%$ who assess integration as 'very good' and $42 \%$ as 'rather good'. When it comes to integration, pessimism prevails as more than $50 \%$ of the Austrian people are skeptical. In $2010,68 \%$ of the questioned thought, that 'integration of migrants functions rather badly or very bad'. Till 2014 these pessimistic assessments decreased down to 51\%. In 2015 and 2017 the mood became increasingly darker; about $60 \%$ assessed integration in Austria negatively. While in 2018 the negative assessments went down to $54 \%,{ }^{79}$ in 2019 the integration process was assessed 'rather bad' by $44 \%$

${ }^{74}$ C. Traulsen: "Art. Kirchenasyl." In: 100 Begriffe aus dem Staatskirchenrecht. Eds. H.M. Heinig, H. Munsonius. Tübingen 22015, pp. 105-107, here p. 106.

${ }^{75}$ R. Geisler: Art. Asyl, Asylrecht (Fn 22), p. 125.

76 C. Traulsen: Art. Kirchenasyl (Fn 74), pp. 106-107.

77 See Republik Österreich. Bundesministerium Für Inneres: Brief von Mag.a Johanna Mikl-Leitner an die Präsidentin des Nationalrates Mag.a Barbara Prammer vom 1. Juli 2011 (GZ: BMI-LR2220/0454-II/3/2011). Available online: https://www.parlament.gv.at/ PAKT/VHG/XXIV/AB/AB_08439/fname_226384.pdf (accessed 10.06.2020).

78 B. Schinkele: "Gewissensgebot und Normativität des positiven Rechts. Überlegungen unter besonderer Berücksichtigung des so genannten »Kirchenasyls«." ÖARR 50 (2003), pp. 448-480, here p. 480.

79 Statistik Austria: Migration \& Integration. Zahlen. Daten. Indikatoren 2018 (Fn 35), p. 92. 
and 'very bad' by $14 \%$. 3\% experienced integrational processes as 'very good' and 39\% as 'rather good'." ${ }^{80}$ State and society are needed. Austria and Europe cannot repress or go over flight and migration. In the context of his first encyclical Redemptor Hominis (1979), John Paul II already emphasised that "the way of the Church" is the human being. ${ }^{81}$ Therefore, refugees and migrants "must not be excluded." "They must not be put into pigeonholes as foreigners, but they have the right to find a home in society and church." 82 Wrong images and unjustified fears have to be shattered. The respective Bishop's Conferences, the individual bishops and priests have a special responsibility, which also impacts parishes and every single Christian. As the ABC's regulations show, baptism of adult asylum seekers demands special attention. The Austrian Bishop's Conference has planned stronger involvement of lay people by enacting a bylaw (1st of February 2002) on courses of catechist-education (in German: Lehrgang zur Ausbildung von Katechisten (LAK)) with a special qualification to foreign-language catechumenate at the Philosophisch-Theologische Hochschule Heiligenkreuz in order to establish the position of catechists in Austria. ${ }^{83}$

${ }^{80}$ See Statistik Austria: Migration \& Integration. Zahlen. Daten. Indikatoren 2019 (Fn 1), p. 94.

${ }^{81}$ John Paul II: Litterae Encyclicae "Redemptor Hominis" ad Venerabiles Fratres in Episcopatu, ad Sacerdotes et Religiosas Familias, ad Ecclesiae filios et filias, necnon ad universos bonae voluntatis homines Pontificali eius ministerio ineunte [4.03.1979], Nr. 14. AAS 71 (1979), pp. 257-324, here 285. Available online: https://w2.vatican.va/content/ john-paul-ii/la/encyclicals/documents/hf_jp-ii_enc_04031979_redemptor-hominis.html (accessed 10.06.2020).

${ }^{82}$ L. VenCSER: Der pastorale Dienst für Migranten/Migrantinnen - Muttersprachliche Seelsorge (Fn 17), p. 55.

83 Cf. ÖsterReichische Bischofskonferenz: "Lehrgang zur Ausbildung von Katechisten (LAK) mit besonderer Befähigung für das fremdsprachige Katechumenat an der Philosophisch-Theologischen Hochschule Heiligenkreuz - Statut." In: Amtsblatt der Österreichischen Bischofskonferenz, Nr. 32 vom 1. Februar 2002, II.2, pp. 11-14. Available online: https://www.uibk.ac.at/praktheol/kirchenrecht/teilkirchenrecht/oebiko/ katechisten.html (accessed 10.06.2020); see also https://www.hochschule-heiligenkreuz. at/willkommen/lak-katechistenkurs/ (accessed 10.06.2020); s. also ÖsterReICHISCHE BISCHOFSKONFERENZ: "Verlängerung des Statuts auf unbestimmte Zeit." In: Amtsblatt der Österreichischen Bischofskonferenz, Nr. 44 vom 15. August 2007, II.2, p. 16. Available online: https://www.uibk.ac.at/praktheol/kirchenrecht/teilkirchenrecht/oebiko/katechisten_2.html (accessed 10.06.2020). 


\section{Bibliography}

\section{Sources}

Bundesamt für Fremdenwesen und Asyl: Asylverfahren. Wien o.J. Available online: https://www.bfa.gv.at/bmi_documents/1954.pdf (accessed 10.02.2020).

Bundesgesetz, mit dem das Bundes-Verfassungsgesetz geändert wird, ein Asylgesetz 2005, ein Fremdenpolizeigesetz 2005 und ein Niederlassungs- und Aufenthaltsgesetz erlassen, das Bundesbetreuungsgesetz, das Personenstandsgesetz, das Bundesgesetz über den unabhängigen Bundesasylsenat, das Einführungsgesetz zu den Verwaltungsverfahrensgesetzen 1991, das Sicherheitspolizeigesetz, das Gebührengesetz 1957, das Familienlastenausgleichsgesetz 1967, das Kinderbetreuungsgeldgesetz und das Tilgungsgesetz 1972 geändert werden sowie das Fremdengesetz 1997 aufgehoben wird (Fremdenrechtspaket 2005). In: BGBl. I Nr. 100/2005. Available online: https://www.ris.bka.gv.at/eli/ bgbl/I/2005/100 (accessed 10.06.2020).

Bundesgesetz über den Asylgerichtshof (Asylgerichtshofgesetz - AsylGHG). In: BGBl. I Nr. 4/2008. Available online: https://www.ris.bka.gv.at/GeltendeFassung.wxe?Abfrage=Bundesnormen \&Gesetzesnummer=20005660\&Fassung Vom $=2013-12-31$ (accessed 10.06.2020).

Bundesgesetz über die Gewährung von Asyl (Asylgesetz 2005 - AsylG 2005). In: BGBl. I Nr. 100/2005. Available online: https://www.ris.bka.gv.at/GeltendeFassung.wxe?Abfrage $=$ Bundesnormen $\&$ Gesetzesnummer $=20004240$ (accessed 10.06.2020).

Bundesgesetz über die Niederlassung und den Aufenthalt in Österreich (Niederlassungs- und Aufenthaltsgesetz - NAG), §§ 51-57a. In: BGBl. I Nr. 100/2005. Available online: https://www.ris.bka.gv.at/GeltendeFassung.wxe?Abfrage=B undesnormen\&Gesetzesnummer=20004242 100 (accessed 10.06.2020].

Bundesgesetz über die Rechtspersönlichkeit von religiösen Bekenntnisgemeinschaften. In: BGBl. I Nr. 19/1998. Available online: https://www.ris.bka.gv.at/ GeltendeFassung.wxe?Abfrage=Bundesnormen\&Gesetzesnummer $=10010098$ (accessed 10.06.2020).

Bundesgesetz über die religiöse Kindererziehung 1985, §5. In: BGBI. Nr. 155/1985. Available online: https://www.ris.bka.gv.at/GeltendeFassung.wxe?Abfrage=B undesnormen\&Gesetzesnummer=20004242 (accessed 10.06.2020).

Charter of Fundamental Rights of the European Union. Available online: https:// eur-lex.europa.eu/legal-content/EN/ALL/?uri=CELEX\%3A12012P\%2FTXT (accessed 10.06.2020).

Congregatio Pro Episcopis: Direttorio per il Ministero pastorale dei Vescovi „Apostolorum

Successors”. Città del Vaticano 2004. Available online: http://www.vatican. va/roman_curia/congregations/cbishops/documents/rc_con_cbishops_ doc_20040222_apostolorum-successores_en.html (accessed 10.06.2020). 
Die Neue Volkspartei/die Grünen - die Grüne Alternative: Aus Verantwortung für Österreich. Regierungsprogramm 2020-2024, Nr. 04. Available online: https://www.dieneuevolkspartei.at/Download/Regierungsprogramm_2020. pdf (accessed 10.06.2020).

Directive 2004/38/EC of the European Parliament and of the Council of 29 april 2004 on the Right of Citizens of the Union and Their Family Members to Move and Reside Freely within the Territory of the Member States Amending Regulation (EEC) No 1612/68 and Repealing Directives 64/221/EEC, 68/360/EEC, 72/194/ EEC, 73/148/EEC, 75/34/EEC, 75/35/EEC, 90/364/EEC, 90/365/EEC and 93/96/EEC (Text with EEA relevance). Available online: https://eur-lex.europa. eu/legal-content/DE/ALL/?uri=CELEX\%3A32004L0038 (accessed 10.06.2020).

ERZDIÖZESE WIEN: Österreichweit gab es 2017 bis zu 750 Erwachsenentaufen. Hauptgrund für die Zunahme von Taufbewerbern - sogenannten „Katechumenen" - aus muslimischen Ländern, die im Zuge der Flüchtlingsbewegung nach Österreich kamen und Christen werden wollen (15.01.2018). Available online: https://www.erzdioezese-wien.at/site/home/nachrichten/ article/62769.html (accessed 10.06.2020).

European Convention for the Protection of Human Rights and Fundamental Freedoms (ECHR) [4.11. 1950]. Available online: https://www.humanrights. ch/en/standards/ce-treaties/echr/ (accessed 10.06.2020).

Francis: Adhortatio Apostolica „Evangelii gaudium" Episcopis, Presbyteris ac diaconis viris et mulieribus consecratis omnibusque christifidelibus laicis de evangelio nuntiando nostra aetate [24.11.2013]. AAS 105 (2013), pp. 1019_ 1137. Available online: http://w2.vatican.va/content/francesco/de/apost_ exhortations/documents/papa-francesco_esortazione-ap_20131124_evangelii-gaudium.html (accessed 10.06.2020).

FrancIs: Litterae Apostolicae Motu Proprio datae "Humanam progressionem" quibus Dicasterium ad integram humanam progressionem fovendam constituitur [17.08. 2016]. AAS 108 (2016), p. 968. Available online: https://w2.vatican. $\mathrm{va} /$ content/francesco/la/motu_proprio/documents/papa-francesco-motu-proprio_20160817_humanam-progressionem.html (accessed 10.06.2020)

Francis: Nachsynodales Apostolisches Schreiben „Christus vivit“ an die jungen Menschen und an das ganze Volk Gottes [25.03.2019], Nr. 94. Available online: http://w2.vatican.va/content/francesco/de/apost_exhortations/ documents/papa-francesco_esortazione-ap_20190325_christus-vivit.html (accessed 10.06.2020).

Francis: Statuto del Dicasterio per il Servizio dello sviluppo umano integrale [17.08. 2016]. AAS 108 (2016), pp. 969-972. Available online: http:// w2.vatican.va/content/francesco/it/motu_proprio/documents/papa-francesco_20160817_statuto-dicastero-servizio-sviluppo-umano-integrale.html (accessed 10.06.2020).

Generalsekretariat der ÖSTERREICHISCHEN BISCHOFSKONFERENZ

(Ed.): Katechumenat. Pastorale Orientierung (= Die österreichischen Bischöfe 14). Wien 2016. Available online: http://www.bischofskonferenz.at/dl/ NpLLJKJKKoolOJqx4K1JK/Heft14_Katechumenat.pdf (accessed 10.06.2020). 
Gesetz vom 20. Mai 1874, betreffend die gesetzliche Anerkennung von Religionsgesellschaften (AnerkennungsG). In: RGB1. Nr. 68/1874. Available online: https://www.ris.bka.gv.at/GeltendeFassung.wxe?Abfrage=Bundesnormen\&G esetzesnummer=10009173 (accessed 10.06.2020).

John Paul II: Constitutio Apostolica "Pastor Bonus" de Romana Curia [28.06.1988], Nr. 149-151. AAS 80 (1988), pp. 841-912. Available online: http://w2.vatican.va/content/john-paul-ii/la/apost_constitutions/documents/ hf_jp-ii_apc_19880628_pastor-bonus-index.html (accessed 10.06.2020).

John PAul II: Epistula Apostolica "Novo millennio ineunte" Episcopis clero fidelibus Magni Iubilaei anni MM sub exitum [6.01.2001], Nr. 55. AAS 93 (2001), pp. 266-309. Available online: https://w2.vatican.va/content/john-paul-ii/ la/apost_letters/2001/documents/hf_jp-ii_apl_20010106_novo-millennioineunte.html (accessed 10.06.2020).

John Paul II: Litterae Encyclicae "Redemptor Hominis" ad Venerabiles Fratres in Episcopatu, ad Sacerdotes et Religiosas Familias, ad Ecclesiae filios et filias, necnon ad universos bonae voluntatis homines Pontificali eius ministerio ineunte (4 March 1979), Nr. 14. AAS 71 (1979), pp. 257-324. Available online: https://w2.vatican.va/content/john-paul-ii/la/encyclicals/documents/ hf_jp-ii_enc_04031979_redemptor-hominis.html (accessed 10.06.2020).

John Paul II: Nuntius ob diem paci dicatum: Diálogo entre las culturas para una civilización del amor y la paz (8 December 2000), Nr. 12. AAS 93 (2001), pp. 234-247. Available online: https://w2.vatican.va/content/john-paul-ii/ de/messages/peace/documents/hf_jp-ii_mes_20001208_xxxiv-world-dayfor-peace.html (accessed 10.06.2020).

Liste der gesetzlich anerkannten Kirchen und Religionsgesellschaften in der Republik Österreich. Available online: https://www.bundeskanzleramt.gv.at/ kirchen-und-religionsgemeinschaften (accessed 10.06.2020).

Österreichische BischofsKonferenz: Asyl und Migration. Available online: https://www.bischofskonferenz.at/positionen/asyl (accessed 10.06.2020).

Österreichische BischofsKonferenz: “Dekret über die Ordnung des Katechumenats can. $788 § 3$ und can. 851, beschlossen am 6. November 1992. Recognitio durch die Kongregation für die Bischöfe am 14. Januar 1994." In: Amtsblatt der Österreichischen Bischofskonferenz, Nr. 11 vom 28. April 1994, Nr. II.2, pp. 3-4. Available online: https://www.uibk.ac.at/praktheol/kirchenrecht/teilkirchenrecht/oebiko/katechumenat.html (accessed 10.06.2020).

ÖsterReICHISCHE BischofsKonferenz: "Fremdsprachige Seelsorge.” In:

Amtsblatt der Österreichischen Bischofskonferenz, Nr. 61 vom 5. Februar 2014. Nr. II.3, p. 11.

ÖSTERREICHISCHE BischofSKONFERENZ: “Lehrgang zur Ausbildung von Katechisten (LAK) mit besonderer Befähigung für das fremdsprachige Katechumenat an der Philosophisch-Theologischen Hochschule Heiligenkreuz - Statut." In: Amtsblatt der Österreichischen Bischofskonferenz, Nr. 32 vom 1. Februar 2002, II.2, pp. 11-14. Available online: https://www.uibk.ac.at/praktheol/kirchenrecht/teilkirchenrecht/oebiko/katechisten.html (accessed 10.06.2020). 
ÖSTERREICHISCHE BISCHOFSKONFERENZ: "Pastorale und rechtliche Richtlinien für die fremdsprachige Seelsorge in Österreich." In: Amtsblatt der Österreichischen Bischofskonferenz, Nr. 22 vom 20. Mai 1998, Nr. II.1, pp. 4-8. Available online: https://www.uibk.ac.at/praktheol/kirchenrecht/teilkirchenrecht/ oebiko/seelsorge_fremdsp.html (accessed 10.06.2020)

ÖSTERREICHISCHE BISCHOFSKONFERENZ: "Richtlinien der österreichischen Bischöfe zum Katechumenat von Asylbewerbern.” In: Amtsblatt der Österreichischen Bischofskonferenz, Nr. 65 vom 20. April 2015, Nr. II.1, pp. 9-14. Available online: https://www.uibk.ac.at/praktheol/kirchenrecht/teilkirchenrecht/ oebiko/katechumenat-asylwerber.html (accessed 10.06.2020).

ÖsterReICHISCHE BischofsKonferenZ: "Richtlinien für den Dienst des Nationaldirektors für die fremdsprachigen Gemeinden im Bereich der Österreichischen Bischofskonferenz." In: Amtsblatt der Österreichischen Bischofskonferenz, Nr. 22 vom 20. Mai 1998, Nr. II.2.

ÖsterReICHISCHE BischofsKonfERENZ: “Richtlinien für die Einführung eines Taufgesprächs mit den Eltern vor der Spendung der Taufe vom März 1971, u.a.” In: Verordnungsblatt für die Diözese Innsbruck, 46. Jg., Nr. 6 vom 1. Juni 1971, Nr. 47, p. 34.

ÖSTERREICHISCHE BisCHOFSKONFERENZ: "Verlängerung des Statuts auf unbestimmte Zeit." In: Amtsblatt der Österreichischen Bischofskonferenz, Nr. 44 vom 15. August 2007, II.2, p. 16. Available online: https://www.uibk.ac.at/praktheol/ kirchenrecht/teilkirchenrecht/oebiko/katechisten_2.html (accessed 10.06.2020).

Österreichische Bundesregierung: Novelle „Asyl auf Zeit“. Pontificium Consilium de Spirituali Migrantium atque Itinerantium Cura: Instruktion „Erga migrantes caritas Christi“ (3 May 2004). AAS 96 (2004), pp. 762-822. Available online: http://www.vatican.va/roman_curia/pontifical_councils/ migrants/documents/rc_pc_migrants_doc_20040514_erga-migrantes-caritas-christi_ge.html (accessed 10.06.2020).

Regulation (EU)NO 604/2013 of the European parliament and of the Council of 26 June 2013 establishing the criteria and mechanisms for determining the Member State responsible for examining an application for international protection lodged in one of the Member States by a third-country national or a stateless person (recast) . Available online: https://eur-lex.europa.eu/LexUriServ/ LexUriServ.do?uri=OJ:L:2013:180:0031:0059:EN:PDF (accessed 10.06.2020).

Republik Österreich. Bundesministerium für InNeres: Asyl. Begriffsbestimmungen. Available online: https://www.bmi.gv.at/301/Allgemeines/Begriffsbestimmungen/start.aspx (accessed 10.06.2020).

RePublik Österreich. Bundesministerium FÜr InNERES: Brief von Mag.a Johanna Mikl-Leitner an die Präsidentin des Nationalrates Mag.a Barbara Prammer vom 1. Juli 2011 (GZ: BMI-LR2220/0454-II/3/2011). Available online: https:// www.parlament.gv.at/PAKT/VHG/XXIV/AB/AB_08439/fname_226384.pdf (accessed 10.06.2020).

Staatsgrundgesetz vom 21. December 1867 über die allgemeinen Rechte der Staatsbürger für die im Reichrathe vertretenen Königreiche und Länder, Art. 14 Abs. 1. 
In: RGBl. Nr. 142/1867. Available online: https://www.ris.bka.gv.at/GeltendeFassung.wxe?Abfrage=Bundesnormen \& Gesetzesnummer $=10000006$ (accessed 10.06.2020).

Statistik Austria: Migration \& Integration. Zahlen. Daten. Indikatoren 2018. Wien 2018. Available online: https://www.bmeia.gv.at/fileadmin/user upload/Zentrale/Integration/Integrationsbericht_2018/Statistisches_Jahrbuch_2018.pdf (accessed 10.06.2020).

Statistik Austria: Migration \& Integration. Zahlen. Daten. Indikatoren 2019. Wien 2019. Available online: https://www.bmeia.gv.at/fileadmin/user upload/Zentrale/Integration/Integrationsbericht_2019/Migration-Integration-2019.pdf (accessed 10.06.2020).

Theologischer Ausschuss der Generalsynode der Evangelischen Kirche A. und H.B. IN ÖSTERrEICH: Handreichung für Taufanfragen, Taufunterricht und Taufe von Asylsuchenden vom Oktober 2014. Available online: http://www.okrevang.at/handreichung_Taufe_Asylsuchende/dokumente/Richtlinien_Generalsynode.pdf (accessed 10.06.2020).

Treaty on the Functioning of the European Union. Available online: https:/eur-lex. europa.eu/legal-content/EN/TXT/?uri=celex\%3A12012E\%2FTXT (accessed 10.06.2020).

UNHCR: Convention relating to the status of refugees and Protocol relating to the status of refugees. Available online: https://www.unhcr.org/3b66c2aa10.html (accessed 10.06.2020).

UNHCR ÖsterReICH: Flucht und Asyl in Österreich. Die häufigsten Fragen und Antworten, 5Wien. Available online: http://www.unhcr.org/dach/wp-content/uploads/sites/27/2018/01/AT_UNHCR_Fragen-und-Antworten_2017.pdf (accessed 10.06.2020).

Universal Declaration of Human Rights. Resolution 217 A (III) (10.12.1948). Available online: http://hrlibrary.umn.edu/instree/b1udhr.htm (accessed 10.06.2020).

\section{Secondary literature}

Ваво M.: Kirchenasyl - Kirchenhikesie. Zur Relevanz eines historischen Modells im

Hinblick auf das Asylrecht der Bundesrepublik Deutschland (= Studien der Moraltheologie 20). Münster-Hamburg-/London 2003, pp. 125-129.

BAIR J., REES W.: Staatlich eingetragene religiöse Bekenntnisgemeinschaften in Österreich (= Religion und Staat im Brennpunkt 3). Innsbruck 2018.

BRICKNER I.: Wie wäre Österreich ohne Migranten? Wie wäre Österreich heute, hätte man die Grenzen vor Jahrzehnten dichtgemacht? Die Vision eines Landes ohne Zuzug von außen (01.09.2018). Available online: https://derstandard.at/2000085768375/Wie-waere-Oesterreich-ohne-Migranten (accessed: 4.05.2019).

Burger K.: Das Verfassungsprinzip der Menschenwürde in Österreich (= Europäische Hochschulschriften, Reihe II Rechtswissenschaft, Bd. 3429). Frankfurt a.M. u.a. 2002. 
De PaOlis V.: “L'impegno della Chiesa nella pastorale della mobilità umana secondo il Codice di Diritto Canonico.” Seminarium 25 (1985), pp. 130c-155c.

DiAKonie: Kleines Asyl-Lexikon. Available online: https://diakonie.at/kleinesasyl-lexikon (accessed 10.06.2020).

Die Presse: Kurz zu UNO-Migrationsbericht: „Lasse es nicht zu, Österreich schlechtzureden“. Das hiesige Asylverfahren weise Mängel auf, kritisiert das UNMenschenrechtshochkommissariat. Kanzler Kurz weist die Vorwürfe zurück und fordert im Gegenzug eine Prüfung aller übrigen EU-Staaten [9.05.2019]. Available online: https://www.diepresse.com/5625131/kurz-zu-uno-migrationsbericht-lasse-es-nicht-zu-osterreich-schlechtzureden (accessed 10.06. 2020).

Die Presse: Salzburger Lehrling nach Kirchenasyl in Schubhaft. Nach zwei negativen Asylbescheiden wurde der 23-jährige Ali Wajid in Schubhaft genommen. Der Menschenrechtsaktivist ist nach wie vor um eine freiwillige Ausreise bemüht [24.01.2019]. Available online: https://diepresse.com/home/ panorama/oesterreich/5568110/Salzburger-Lehrling-nach-Kirchenasyl-inSchubhaft (accessed 10.06.2020).

Die Presse: „Unmenschlich“: Schönborn rechnet mit Asylpolitik der Regierung ab. In der ORF-,Pressestunde“ übt Kardinal Christoph Schönborn scharfe Kritik an der Regierung: „Eine kleine Gruppe von Menschen wird offensichtlich systematisch in ein schiefes Licht gerückt“ [14.04.2019]. Available online: https:// diepresse.com/home/panorama/religion/5612554/Unmenschlich_Schoenborn-rechnet-mit-Asylpolitik-der-Regierung-ab (accessed 10.06.2020).

Evang.AT / Schiefermair K.: Pfarrgemeinden leisten wertvolle Integrationsarbeit. Oberkirchenrat Schiefermair kritisiert „absurde“ Glaubensprüfungen im Asylverfahren [20.12.2017]. Available online: https://evang.at/oberkirchenrat-pfarrgemeinden-leisten-bei-fluechtlingen-wertvolle-integrationsarbeit/ (accessed 10.06.2020).

Geisler R.: “Art. Asyl, Asylrecht (Th).” In: EvStLex9, Sp. 122-126.

Hauser G.: "Migration - ein Sicherheitsproblem?" In: Westliche, universelle oder christliche Werte? Menschenrechte, Migration, Friedenspolitik im Europa des 21. Jahrhunderts (= Ethica Themen. Institut für Religion und Frieden). Eds. G. Marchl, C. Wagnsonner. Wien 2012, pp. 75-99.

Haering S.: "Kirche und Staat in der Sicht des Zweiten Vatikanischen Konzils und die Auswirkungen im Codex Iuris Canonici. Zur modernen Antwort der katholischen Kirche auf eine jederzeit aktuelle Frage." In: Ius canonicum in communione christifidelium. Festschrift 65. Geburtstag von Heribert Hallermann (= KStKR 23).Eds. M. Graulich, T. Meckel, M. Pulte M. Paderborn 2016, pp. 83-98.

Kalb H., Potz R., Schinkele B.: Religionsrecht. Wien 2003.

Katholische Kirche ÖsterReICH: Erzdiözese Salzburg stützt „Gewissensentscheidung" des Unkener Pfarrers, einen von Abschiebung bedrohten afghanischen Kochlehrling zu beherbergen [12.11.2019]. Available online: https://www. katholisch.at/aktuelles/127874/kirchenasyl-in-unken-kirche-fuer-vernunftund-barmherzigkeit (accessed 10.06.2020). 
KATHOLISCHE KIRCHE ÖSTERREICH: Weiterhin hohe Zahl an katholischen Erwachsenentaufen. Kirche rechnet für 2019 mit 500 Taufen von Personen ab 14 Jahren, davon über 200 aus der Erzdiözese Wien [8.03.2019]. Available online: https:// www.katholisch.at/aktuelles/124945/weiterhin-hohe-zahl-an-katholischenerwachsenentaufen (accessed 10.06.2020).

Katholische Kirche Österreich / Schipka P.: Bischofskonferenz gegen Höchstbetrag für Asylwerber-Arbeiten. Generalsekretär Schipka sieht keine Notwendigkeit einer Stundenlohnlimitierung bei gemeinnützigen Tätigkeiten durch das Innenministerium [12.04.2019]. Available online: https://www.katholisch. at/aktuelles/125365/bischofskonferenz-gegen-hoechstbetrag-fuer-asylwerberarbeiten (accessed 10.06.2020).

KATZINGER G.: Kirchenrechtliche Anmerkungen zur Migrantenseelsorge in einer globalisierten Welt. In: Recht - Bürge

der Freiheit. Festschrift für Johannes Mühlsteiger SJ zum 80. Geburtstag (= KST 51). Eds. K. Breitsching, W. Rees. Berlin 2006, pp. 787-826.

KessLer T.: Kurienreform. Die Zusammenführung verschiedener Dikasterien betrifft auch die Migrantenseelsorge. Available online: https://iwm.sankt-georgen. de/kurienreform-betrifft-auch-migrantenseelsorge/ (accessed 10.06.2020).

KURIER: Regierung beschließt „Asyl auf Zeit“. ÖVP zufrieden: Österreich habe nun eines der schärfsten Asylgesetze in ganz Europa [26.01.2016]. Available online: https://kurier.at/politik/inland/regierung-beschliesst-asyl-aufzeit/177.262.265 [last downloaded: 10.02.2020].

LeDerhilger S.J.: Seelsorge am Menschen unterwegs. In: HdbKathKR3, pp. 768775.

ORF: Hunderte Muslime wechseln zum Christentum. Die Flüchtlingskrise beschert der katholischen Kirche in Österreich eine Rekordzahl an Menschen, die vom Islam zum Christentum wechseln. Allein in Wien haben sich 260 Menschen aus 15 Nationen taufen lassen [13.01.2018]. Available online: https://religion. orf.at/stories/2889262/ (accessed 10.06.2020).

Österreich.gv.at: Asyl. Aktuelle Informationen zu Asyl, Asylverfahren, Familienverfahren, Ausweise und Dokumente, Rechtsberatung [1.01.2020]. Available online: https://www.oesterreich.gv.at/themen/leben_in_oesterreich/asyl. html (accessed 10.06.2020).

ÖSTERREICHISCHE BISCHOFSKONFERENZ: Bischofskonferenz fordert eine parteiische Rechtsberatung [12.04.2019]. Available online: https://www.bischofskonferenz.at/125366/bischofskonferenz-fordert-parteiische-rechtsberatung (accessed 10.06.2020); text available online for a download: https://www. bischofskonferenz.at/dl/lpLuJKJKkMLmmJqx4KJK/2019_04_12_BMI_BBUErrichtungsgesetz_Stellungnahme_PDF.pdf (accessed 10.06.2020).

ÖSTERREICHISCHE BISCHOFSKONFERENZ: Bischofskonferenz gegen Asylnotverordnung. Bischöfe orten keinen öffentlichen Notstand - Gegen Verschärfung des Asylrechts. Available online: https://www.bischofskonferenz.at/asyl/bischofskonferenz-gegen-asyl-notverordnung (accessed 10.06.2020).

ÖSTERREICHISCHE BISCHOFSKONFERENZ: Bischofskonferenz lehnt geplante Asylverschärfung $a b$. Bischöfe kritisieren Gesetzesentwurf als negativen Paradigmen- 
wechsel und nicht akzeptablen Eingriff in Grundrecht, der bestehendes Recht auf Asyl maßgeblich einschränkt — Warnung vor europaweiter Dynamik, die das Recht auf Asyl faktisch aushebelt [22.04.2016]. Available online: https:// www.bischofskonferenz.at/asyl/bischofskonferenz-lehnt-geplante-asylverschaerfungen-ab [last downloaded: 10.06.2020).

Pulte M.: Grundfragen des Staatskirchen- und Religionsrechts (= Mainzer Beiträge zu Kirchen- und Religionsrecht 1). Würzburg 2016.

ReEs W.: “»Migration ist eine Schlüsselfrage für die Zukunft der Menschheit« (Papst Franziskus 2019). Kirchen- und religionsrechtliche Vorgaben zu Asyl, Religionswechsel und Seelsorge an Migranten in Österreich.” In: ReEs W./ HAering S. (Ed.): Festschrift für Johann Hirnsperger (KST). Berlin 2020 (in press).

REES W.: "Reformen in der römisch-katholischen Kirche. Kirchenrechtliche Neuerungen und Visionen von Papst Franziskus.” ÖARR 64 (2017), pp. 410-427 (= Herbert Kalb zum 60. Geburtstag).

Schinkele B.: “Gewissensgebot und Normativität des positiven Rechts. Überlegungen unter besonderer Berücksichtigung des so genannten »Kirchenasyls«." ÖARR 50 (2003), pp. 448-480.

Traulsen C.: “Art. Kirchenasyl." In: Heinig H.M./Munsonius H. (Ed.): 100 Begriffe aus dem Staatskirchenrecht. Tübingen 22015, pp. 105-107.

Vatican News: Vor fünf Jahren: Franziskus bei Migranten auf Lampedusa. Es war die erste Reise als Papst überhaupt: Vor genau fünf Jahren besuchte Franziskus Migranten auf der Insel Lampedusa vor Sizilien. Und warf einen Kranz ins Meer, zum Gedenken an alle während der Überfahrt nach Europa Verstorbenen [6.07.2018], https://www.vaticannews.va/de/papst/news/2018-07/ franziskus-papst-besuch-fluechtlinge-lampedusa-migranten.html (accessed 10.06.2020).

Vencser L.: “Der pastorale Dienst für Migranten/Migrantinnen - Muttersprachliche Seelsorge." In: Migration und Integration: Pastorale Herausforderungen und Chancen. Eds. W. Krieger, B. Sieberer. Linz 2013, pp. 54-75.

WILHELM REES

Aide pastorale aux migrants. Dispositions du droit canonique et religieux concernant l'asile et le changement de confession

Résumé

Les réfugiés et les migrants ont toujours fait l'objet d'une préoccupation particulière de l'Église catholique romaine et de ses activités pastorales. Même si l'afflux important de réfugiés en 2015 et 2016 en Autriche est terminé, la fuite et la migration y restent des sujets d'actualité. Cet article porte sur plusieurs questions : l'évolution historique des réglementations canoniques, la situation des réfugiés et des migrants en Autriche, les 
bases juridiques, la mise en ouvre des procédures d'asile et des chiffres, les déclarations officielles de la Conférence épiscopale autrichienne, l'adhésion à l'Église ou à la communauté religieuse et la conversion, le problème de l'appartenance à l'Église catholique comme condition nécessaire au salut, les règlements sur le catéchuménat et sur l'asile ecclésiastique. L'auteur présente des chiffres, des données et des faits, il présente et analyse le statut canonique et juridique apportant des clarifications aux questions peu claires pour éventuellement aider dans leur étude plus approfondie.

Mots clés : réfugiés, migration, droit canonique, asile, République d'Autriche

WiLHELM ReES

\title{
Assistenza pastorale ai migranti. Disposizioni di diritto canonico e religioso in materia di asilo e di cambio di religione
}

\begin{abstract}
Rifugiati e migranti sono sempre stati oggetto di particolare interesse della Chiesa cattolica romana e delle sue attività pastorali. Anche se il grande afflusso di rifugiati del 2015 e 2016 in Austria è terminato, la fuga e la migrazione rimangono questioni di attualità. Questo articolo affronta diverse questioni: lo sviluppo storico delle norme canoniche, la situazione dei rifugiati e dei migranti in Austria, le basi legali, l'attuazione delle procedure di asilo e i numeri, le dichiarazioni ufficiali della Conferenza episcopale austriaca, l'adesione alla Chiesa o alla comunità religiosa e la conversione, il problema dell'appartenenza alla Chiesa cattolica come necessaria per la salvezza, le norme sul catecumenato e sull'asilo ecclesiastico. L'autore presenta cifre, dati e fatti, espone e analizza lo status canonico e giuridico chiarendo questioni offuscate per aiutare eventualmente nel loro ulteriore studio.
\end{abstract}

Parole chiave: rifugiati, migrazione, diritto canonico, asilo, Repubblica d'Austria 